University of Nebraska - Lincoln

DigitalCommons@University of Nebraska - Lincoln

Faculty Publications in Food Science and Technology

$2-2020$

\title{
Integration of sodium hypochlorite pretreatment with co- immobilized microalgae/bacteria treatment of meat processing wastewater
}

Xinjuan Hu

Yulie Meneses

Ashraf Aly Hassan

Follow this and additional works at: https://digitalcommons.unl.edu/foodsciefacpub

Part of the Civil and Environmental Engineering Commons, and the Food Science Commons

This Article is brought to you for free and open access by the Food Science and Technology Department at DigitalCommons@University of Nebraska - Lincoln. It has been accepted for inclusion in Faculty Publications in Food Science and Technology by an authorized administrator of DigitalCommons@University of Nebraska Lincoln. 


\title{
Integration of sodium hypochlorite pretreatment with co-immobilized microalgae/bacteria treatment of meat processing wastewater
}

\author{
Xinjuan Hu, ${ }^{1}$ Yulie E. Meneses, ${ }^{1,2}$ Ashraf Aly Hassan ${ }^{3,4}$ \\ 1 Department of Food Science and Technology, Food Processing Center, University of \\ Nebraska-Lincoln, Lincoln, NE 68588-6205, United States \\ 2 Daugherty Water for Food Global Institute, Nebraska Innovation Campus, University \\ of Nebraska-Lincoln, Lincoln, NE 68588-6204, United States \\ 3 Department of Civil and Environmental Engineering and National Water Center, \\ United Arab Emirates University, Al Ain, Abu Dhabi, United Arab Emirates \\ 4 Department of Civil Engineering, University of Nebraska-Lincoln, Lincoln, NE \\ 68588-0531, United States \\ Corresponding author - Y.E. Meneses, Department of Food Science and Technology, \\ University of Nebraska-Lincoln, Food Innovation Center, 1901 N 21st ST, Lincoln, \\ NE 68588-6205, United States. Email yuliemeneses@unl.edu
}

\begin{abstract}
Wastewater with $0.2,0.4,0.8,1.0 \mathrm{mg} / \mathrm{L}$ free chlorine was biologically treated using co-immobilized microalgae/ bacteria. In contrast, non-pretreated wastewater was treated with beads (control) and blank beads (blank) under the same operating condition. Results showed that $\mathrm{NaClO}$ pretreatment removed $8-33 \%$ total nitrogen (TN), 31-45\% true color and 0.7-2.5 log CFU/mL aerobic-bacteria. At the end of treatment, maximum algal biomass (2,027 dry weight $\mathrm{mg} / \mathrm{L}$ ) was achieved with 0.2 $\mathrm{mg} / \mathrm{L}$ free chlorine. Bacterial growth in wastewater was decreased by $\mathrm{NaClO}$ pretreatment before reaching $7.2-7.7 \log \mathrm{CFU} / \mathrm{mL}$ on the fifth day. Beads with microor-
\end{abstract}

Published in Bioresource Technology 304 (2020), 122953

doi:10.1016/j.biortech.2020.122953

Copyright (c) 2020 Elsevier Ltd. Used by permission.

Submitted 26 November 2019; revised 28 January 2020; accepted 3 February 2020;

published 4 February 2020. 
ganisms (control) removed 15\% more chemical-oxygen-demand (COD), 16\% more $\mathrm{TN}$, and $13 \%$ more total phosphate $\left(\mathrm{PO}_{4}{ }^{3-}\right)$ than blank. Pretreatment with $0.2 \mathrm{mg} / \mathrm{L}$ free chlorine increased $\mathrm{TN}$ removal from $75 \%$ to $80 \%$ while pollutants removal was substantially decreased with $0.4-1.0 \mathrm{mg} / \mathrm{L}$ free chlorine. Considering algal biomass growth and pollutants removal, $0.2 \mathrm{mg} / \mathrm{L}$ free chlorine pretreatment was recommended for microalgae/ bacteria co-immobilized system.

Keywords: Wastewater, Microalgae, Activated sludge bacteria, Co-immobilization, Chlorine

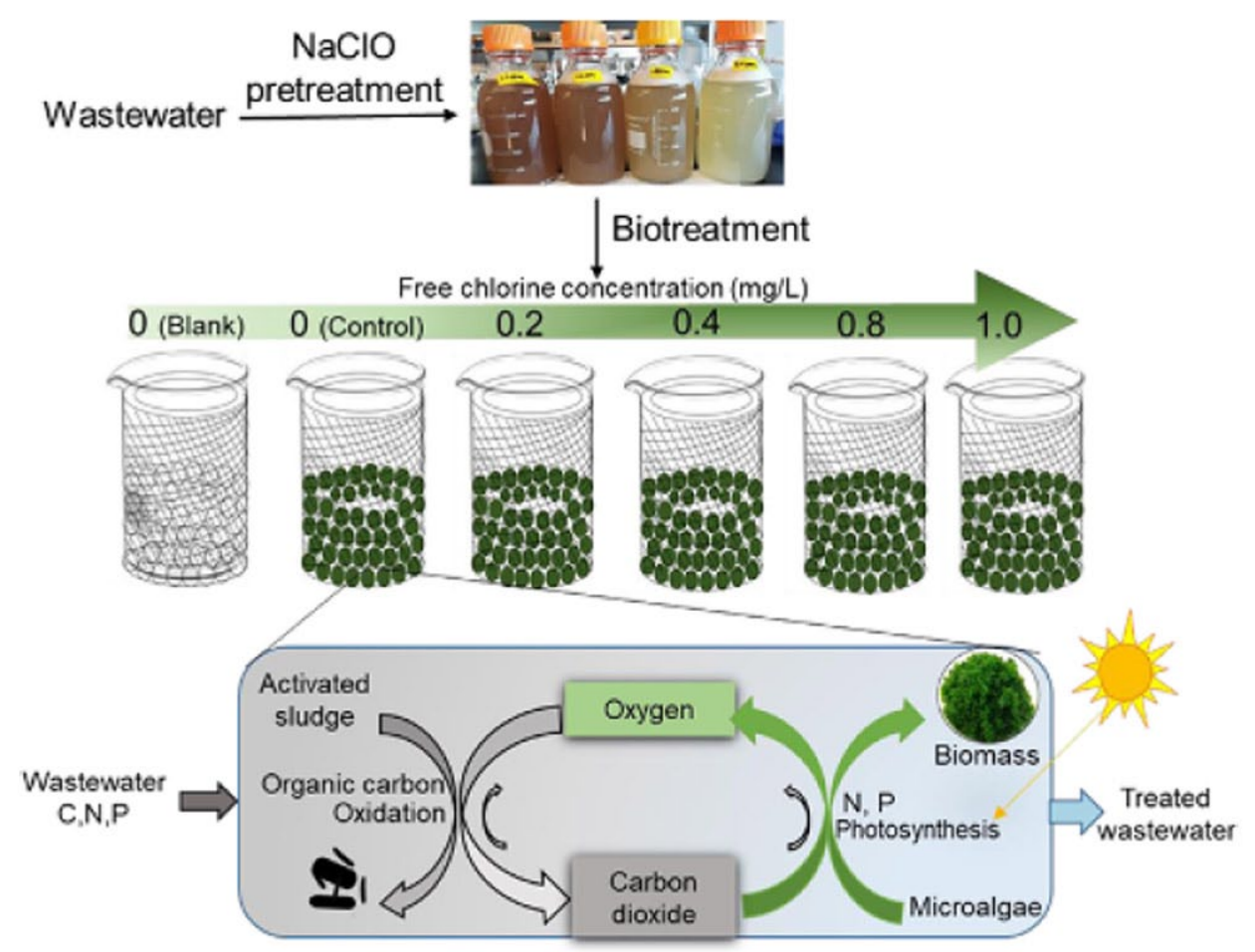

\section{Introduction}

Microalgae, a category of fast-growing photosynthetic microorganisms in water, have demonstrated high efficiency for biological assimilation of nitrogen and phosphorus from various sources including highly polluted wastewater (Goncalves et al., 2016). Wastewater treatment using microalgae is promising owing to the efficient uptake of $\mathrm{CO}_{2}$ and the growth of algal biomass rich in compounds like lipid and protein (Maity et al., 2014). However, one significant pitfall of this technology is the recovery of suspended algal biomass attributed to 
the small size (3-30 $\mu \mathrm{m})$ and negative charges of microalgae cell which prevents their auto-aggregation (Barros et al., 2015). To address this challenge, the technology of immobilization has been widely studied (de-Bashan and Bashan, 2010). Compared to physical centrifugation and chemical coagulation/flocculation, algal biomass harvesting through immobilization consumes less energy and the obtained biomass is less contaminated by metal hydroxides (Anthony et al., 2013). Among various immobilization approaches, co-immobilization of microalgae with symbiotic bacteria using alginate gel has been found efficient in wastewater treatment (de-Bashan and Bashan, 2010). In the co-immobilized algae/bacteria system, microalgae growth can benefit from the existence of symbiotic bacteria and also, organic pollutants removal by bacteria and nutrients assimilation by microalgae could possibly be achieved simultaneously (de-Bashan et al., 2002; Xie et al., 2018). Mujtaba et al. (2017) showed that the co-culture of immobilized microalgae and activated sludge removed $98-100 \%$ nitrogen, 92-100\% phosphorus, and 94-96\% COD from wastewater.

Nevertheless, most of the current studies were conducted using artificial or sterilized wastewater which has a different composition from real wastewater (Cheirsilp et al., 2017; Shen et al., 2017). Many factors need to be considered for the treatment of real wastewater. Firstly, most industrial wastewater is characterized by high turbidity and dark color which limits photosynthesis of microalgae. Also, alginate beads are susceptible to degradation by various pollutants in the case of real wastewater. For instance, under alkaline $\mathrm{pH}$ crosslinking ions of calcium in alginate gel will bind with chelating agents like phosphate or citrate to decay the mechanical strength of alginate beads (Ruiz-Marin et al., 2010). Apart from the complex chemical environment, the presence of alginate-degrading bacteria in wastewater is another crucial factor decreasing gel strength and stability of alginate beads (Cruz et al., 2013). Additionally, the existence of phytoplankton-lytic bacteria and protozoa in wastewater will compete with or predate microalgae and restrict biomass growth (Wang et al., 2013). Consequently, in most studies (see Table 1), industrial wastewater was usually pretreated with autoclave, membrane filtration and centrifugation or high dilution before being treated with microalgae which are not applicable considering the amount of wastewater produced by the food industry. 
Table 1 Pretreatment applied to wastewater before being treated with microalgae.

\begin{tabular}{|c|c|c|c|}
\hline Microalgae & Wastewater source & Pretreatment & Reference \\
\hline C. vulgaris & Swine farm & $\begin{array}{l}\text { Centrifugation + Membrane filtration } \\
+ \text { Dilution + Autoclave }\end{array}$ & Wang et al. (2015) \\
\hline C. pyrenoidosa & Soybean processing & Centrifugation + Autoclave & Su et al. (2011) \\
\hline S. obliquus & Olive-oil extraction & Membrane filtration + Dilution & Hodaifa et al. (2008) \\
\hline Chlorella sp. & Brewery & Centrifugation + Autoclave & Farooq et al. (2013) \\
\hline C. vulgaris & Molasses & Centrifugation + Autoclave & Yang et al. (2019) \\
\hline $\begin{array}{l}\text { C. sorokiniana, } \\
\text { S. obliquus, } \\
\text { S. abundans }\end{array}$ & Food processing & Centrifugation + Autoclave & Gupta and Pawar (2018) \\
\hline $\begin{array}{l}\text { Scenedesmus sp., } \\
\text { Chlorella sp. }\end{array}$ & Palm oil mill & Centrifugation + Dilution & Hariz et al. (2019) \\
\hline Scendesmus sp. & Textile desizing & Anaerobic digestion + Dilution & Lin et al. (2017) \\
\hline C. pyrenoidosa & Starch processing & Membrane filtration + Autoclave & Tan et al. (2018) \\
\hline Mixed algae species & Slaughterhouse & $\begin{array}{l}\text { Membrane filtration + Autoclave } \\
+ \text { Dilution }\end{array}$ & Taşkan (2016) \\
\hline
\end{tabular}

$\mathrm{NaClO}$ is a strong oxidizing agent and extensively used in municipal wastewater treatment plants to disinfect wastewater before being discharged to the environment. As a disinfectant, $\mathrm{NaClO}$ showed high efficiency inactivating a wide variety of aquatic microorganisms. Consequently, the lower bacteria load in the wastewater benefited microalgae growth and allowed higher alginate beads stability. Zhu et al. (2013) showed that performance (nutrients removal, biomass growth and lipid production) of Chlorella zofingiensis growing in $\mathrm{Na}-$ $\mathrm{ClOpretreated} \mathrm{wastewater} \mathrm{was} \mathrm{similar} \mathrm{to} \mathrm{the} \mathrm{autoclaved} \mathrm{samples.} \mathrm{Be-}$ sides, pretreatment of $\mathrm{NaClO}$ can generate free chlorine which can provide lasting disinfection effect and control external contamination during microalgae cultivation. Park et al. (2016) determined that chlorine dosage between 0.45 and $0.60 \mathrm{mg} \mathrm{Cl} / \mathrm{L}$ with a dosing interval of two hours could continually inhibit the predation of rotifer without affecting microalgae growth in open pond system. Advanced oxidation with $\mathrm{NaClO}$ will also bleach the dark color, improve light transmission and oxidize toxic pollutants like detergents and phenols in wastewater, which in turn improves later microalgae-based treatment. For example, pretreatment of olive mill wastewater using $\mathrm{NaClO}$ reduced $45 \%$ toxic phenol and $75 \%$ turbidity making olive mill wastewater suitable for microalgae growth (Markou et al., 2012). In NaClO 
pretreated dairy wastewater, algal biomass increased from 0.861 to $1.339-1.870 \mathrm{~g} / \mathrm{L}$ and was higher than the growth observed in UV pretreated wastewater (Qin et al., 2014).

However, most of the present studies associated with pretreatment of $\mathrm{NaClO}$ are conducted using a suspended microalgae system. Coimmobilization of microalgae and symbiotic bacteria is a promising technology for biomass harvesting and pollutants removal. Integration of pretreatment using $\mathrm{NaClO}$ with a co-immobilized microalgae/bacteria system is expected to improve and simplify wastewater treatment while facilitating nutrients recovering and algal biomass harvesting. Thus, in the present study primary treated meat processing wastewater was sampled, and the effect of pretreatment with $\mathrm{NaClO}$ at different free chlorine concentrations on quality of wastewater and pollutants removal as well as the growth of microorganisms was evaluated.

\section{Materials and methods}

\subsection{Meat processing wastewater}

Wastewater was collected from a beef packaging plant located in the Midwest. Like many food processing facilities, this plant used dissolved air flotation (DAF) as a primary treatment. Wastewater was stored at $4{ }^{\circ} \mathrm{C}$ and large non-soluble particulate solids were removed by sedimentation.

\subsection{Beads preparation}

Microalgae strains of Scendesmus obliquus UTEX B2630, Chlorella vulgaris UTEX 259, and Chlorella sorokiniana UTEX 1230 were obtained from Fatty Acid Transport, Trafficking and Transcriptional Regulation Laboratory at the University of Nebraska-Lincoln. They were inoculated and cultivated in modified Bold's Basal media (MBBM) which was prepared according to the method described by Starr and Zeikus (1993). Cultivation was conducted in a MAXQ4000 orbital shaking incubator (Thermal Scientific, USA) at the rate of $125 \mathrm{rpm}$ with 56 $\mu \mathrm{mol}$ photons $/ \mathrm{m}^{2} / \mathrm{s}$ continuous fluorescent light and $25 \pm 2{ }^{\circ} \mathrm{C}$ for seven days. Light intensity was measured with $\mathrm{LI}-250$ light meter (LICOR, USA). Meanwhile, activated sludge bacteria were collected from 
secondary treatment of a local municipal wastewater treatment plant and enriched in the laboratory. Cells of microalgae and bacteria were harvested by centrifugation at 3,500 rpm for $10 \mathrm{~min}$. Pellets were resuspended in deionized water to reach total suspended solids (TSS) concentration of $32.63 \mathrm{~g} / \mathrm{L}$. Sodium alginate $(2.5 \% \mathrm{w} / \mathrm{v})$ was mixed with microalgae suspension and activated sludge suspension at a volumetric ratio of $8: 1: 1$ to achieve a final alginate mixture of $2 \%(\mathrm{w} / \mathrm{v})$. Uniform beads were formed by dropping alginate mixture into $1 \%$ $(\mathrm{w} / \mathrm{v}) \mathrm{CaCl}_{2}$ using a syringe pump (Harvard, USA). Blank beads were prepared following the same method except that the microalgae and activated sludge portion were replaced by deionized water. Gel beads with an average diameter of $3.4 \mathrm{~mm}$ were produced and stabilized in $1 \%(\mathrm{w} / \mathrm{v}) \mathrm{CaCl}_{2}$ solution at $4{ }^{\circ} \mathrm{C}$ overnight. They were rinsed with deionized water before being applied in wastewater treatment.

\subsection{Pretreatment with $\mathrm{NaClO}$}

Wastewater pretreatment using $\mathrm{NaClO}$ was conducted with the method described by Macauley et al. (2006) with modifications. Commercial bleach containing $8.25 \%(\mathrm{w} / \mathrm{v}) \mathrm{NaClO}$ was purchased from a local store and used as chlorinating agents. Sodium hypochlorite has strong oxidant capacity and will oxidize organic compounds and microorganisms in wastewater to be partially consumed. In a preliminary experiment, $550 \mathrm{~mL}$ wastewater was pretreated with $0.88,1.76$, 3.52 , and $4.40 \mathrm{~mL}$ commercial bleach and left at room temperature. After three hours of frequent mixing, the free chlorine concentrations reached $0.2,0.4,0.8,1.0 \mathrm{mg} / \mathrm{L}$, respectively. All apparatus were sterilized to avoid contamination. Free chlorine concentration was measured immediately at the end of pretreatment. Meanwhile, concentrations of chemical oxygen demand (COD), total nitrogen (TN), total phosphate $\left(\mathrm{PO}_{4}{ }^{3-}\right), \mathrm{pH}$ and color as well as aerobic-bacteria plate counts (APC) were determined in wastewater before and after $\mathrm{NaClO}$ pretreatment.

\subsection{Experimental setup}

Three types of treatments were studied to determine the effect of pretreatment of $\mathrm{NaClO}$ on co-immobilized microalgae/bacteria system. First, following the pretreatment of $\mathrm{NaClO}$ beads were applied im- 
mediately to the wastewater with $0.2-1.0 \mathrm{mg} / \mathrm{L}$ free chlorine. At the same time, control treatment (beads + non-pretreated wastewater) and blank (blank beads + non-pretreated wastewater) were conducted by adding the same amount of beads and blank beads to non-pretreated wastewater. All of these treatments were performed following the same approach where beads were applied at the volumetric ratio of beads: wastewater of 1:5. To increase the efficiency of light, gas, and nutrients diffusion among beads, an annular reactor where beads being vertically laid against the glass wall in thin layers was built instead of having beads stacking up at the bottom. All of the treatments were conducted in a refrigerated incubator (Precision, USA) for seven days, under the conditions as follows: 125 rpm, lightness: darkness $=16 \mathrm{~h}: 8 \mathrm{~h}$ at $20^{\circ} \mathrm{C}$. The intensity of fluorescent light was set to be $84 \mu \mathrm{mol}$ photons $/ \mathrm{m}^{2} / \mathrm{s}$, which was the highest value that the incubator could provide. Pollutants removal of $\mathrm{COD}, \mathrm{TN}$ and total $\mathrm{PO}_{4}{ }^{3-}$ as well as the growth of bacteria (using APC) in wastewater and microalgae immobilized in beads were determined on the first, third, fifth and seventh day of the treatment.

\subsection{Analytical methods}

\subsubsection{Wastewater characteristics}

To determine pollutants concentration, $5 \mathrm{~mL}$ of wastewater was sampled and centrifuged at $4000 \mathrm{rpm}$ for $10 \mathrm{~min}$. With the proper dilution of deionized water, the concentration of soluble COD, TN, total $\mathrm{PO}_{4}{ }^{3-}$ in wastewater were measured following standard methods of dichromate digestion, molybdovanadate and persulfate digestion with $\mathrm{HACH}$ analysis kits. TNT tubes were digested and read using DRB 200 digester $(\mathrm{HACH}, \mathrm{USA})$ and DR 3900 spectrophotometer $(\mathrm{HACH}$, USA). The percentage removal of $\mathrm{COD}, \mathrm{TN}$, and total $\mathrm{PO}_{4}{ }^{3-}$ were calculated with Eq. (1):

The percentage removal of pollutant $(\%)=(a-b) / a \times 100$

where $a$ and $b$ are the concentration of $\mathrm{COD} / \mathrm{TN} /$ total $\mathrm{PO}_{4}{ }^{3-}$ at the starting point and during treatment, respectively.

The true color of wastewater was measured according to the platinum-cobalt standard method $(\mathrm{HACH}, 2014)$ with a 3900 spectrophotometer $(\mathrm{HACH}, \mathrm{USA})$. To guarantee readings were within the de- 
signed range, wastewater was diluted with deionized water. $\mathrm{pH}$ was measured with a digital pH meter (Fisher Scientific, USA). Due to the limitation of high turbidity and dark color in wastewater, a method based on colorimeter and titration could not be applied in determining the free chlorine concentration. Test strips (HF Scientific Inc, USA) which are widely used in industrial was adopted in this study (lowest detection limit $=0.05 \mathrm{mg} / \mathrm{L}$ ). APC was measured following the technique of serial dilution with plate count agar (Thermo Scientific, USA) at $37^{\circ} \mathrm{C}$ for $48 \mathrm{~h}$.

\subsubsection{Growth of immobilized microalgae}

To determine the growth of immobilized microalgae, three beads were taken and the average weight of dry algal biomass in one bead was measured. Subsequently, it was multiplied with bead counts required to treat one liter of wastewater to estimate the weight of dry algal biomass grown in one liter of wastewater. The method described by Shen et al. (2017) was adopted with modifications to release algal cells from alginate beads and determine chlorophyll concentration which was correlated to the concentration of dry weight (DW) of algal biomass with the pre-developed standard curve. Three beads were dissolved in $5 \mathrm{~mL}$ of $4 \%(\mathrm{w} / \mathrm{v}) \mathrm{NaHCO}_{3}$. Microalgae cells were separated by centrifugation at $5000 \mathrm{rpm}$ for $10 \mathrm{~min}$ and pellets were washed with $5 \mathrm{~mL}$ deionized water. Chlorophyll extraction was performed with $5 \mathrm{~mL}$ of dimethyl sulfide (DMSO). To accelerate cell rupture and increase chlorophyll extraction rate, a mixture of DMSO and algal cells were sonicated (Branson, USA) for 20 min, where an ice-water bath was used to avoid overheating. Finally, sonicated samples were left in darkness for two hours to complete chlorophyll extraction. Suspended cell debris was removed through centrifugation at $5000 \mathrm{rpm}$ for $10 \mathrm{~min}$ at $10{ }^{\circ} \mathrm{C}$ to obtain a clear supernatant for measuring chlorophyll concentration at $663 \mathrm{~nm}$ (Abs $663 \mathrm{~nm}$ ) using a UV/Vis UV-1800 spectrophotometer (Shimadzu, Japan). Algal biomass cultivated in one liter of wastewater was calculated following Eq. (2).

Algal biomass(DWmg/L wastewater)

$$
=3.4306 \times \text { Abs } 663 \mathrm{~nm} \times 2,700 \quad R^{2}=0.95
$$




\subsection{Statistical analysis}

Two samples were prepared for each treatment, and all experiments were conducted twice. Measured parameters were reported as mean \pm standard deviation. Pair-Wise comparison was conducted using SAS (9.4) to determine the significance of difference at the level of $P=$ 0.05 .

\section{Results and discussion}

\subsection{Impact of $\mathrm{NaClO}$ pretreatment on wastewater quality}

Concentrations of soluble $\mathrm{COD}, \mathrm{TN}$, total $\mathrm{PO}_{4}{ }^{3-}$ in wastewater without (control) and with $\mathrm{NaClO}$ pretreatment are presented in Table 2. In contrast to control, the concentration of $\mathrm{COD}$ in $\mathrm{NaClO}$ pretreated wastewater was higher but did not present significant $(P>0.05)$ difference. A similar phenomenon was also noticed by Plummer and Edzwald (2002) and it is attributed to the strong oxidation capability of chlorine which oxidizes part of large-non-soluble organic molecules such as fat into soluble ones (e.g., fatty acid) (Wang et al., 2017). The effect of $\mathrm{NaClO}$ pretreatment on total $\mathrm{PO}_{4}{ }^{3-}$ concentration was insignificant $(P>0.05)$. On the contrary, $2-33 \% \mathrm{TN}$ was removed from the wastewater after pretreatment and the concentration of TN was reduced from $154.6 \mathrm{mg} / \mathrm{L}$ to $103.1-151.4 \mathrm{mg} / \mathrm{L}$. Also, the $\mathrm{pH}$ in wastewater decreased from 6.8 to 5.8. This is consistent with results obtained by Qin et al. (2014) who reported that total Kjeldahl nitrogen (TKN) was reduced from 85.5 to $59.0 \mathrm{mg} / \mathrm{L}$ when available chlorine concen-

Table 2 Wastewater characteristic before and after $\mathrm{NaClO}$ pretreatment.

\begin{tabular}{lllllll}
$\begin{array}{l}\text { Free chlorine } \\
\text { concentration }(\mathrm{mg} / \mathrm{L})\end{array}$ & $\begin{array}{l}\mathrm{COD} \\
(\mathrm{mg} / \mathrm{L})\end{array}$ & $\begin{array}{l}\mathrm{Total} \mathrm{PO}_{4}{ }^{3-} \\
(\mathrm{mg} / \mathrm{L})\end{array}$ & $\begin{array}{l}\mathrm{TN} \\
(\mathrm{mg} / \mathrm{L})\end{array}$ & $\mathrm{pH}$ & $\begin{array}{l}\text { True color } \\
(\mathrm{PtCo})\end{array}$ & $\begin{array}{l}\mathrm{APC} \\
(\mathrm{log} \mathrm{CFU} / \mathrm{mL})\end{array}$ \\
\hline Control & $1,868 \pm 2 \mathrm{a}$ & $126.9 \pm 0.4 \mathrm{a}$ & $154.6 \pm 8.3 \mathrm{a}$ & $6.8 \pm 0.2 \mathrm{a}$ & $1,562 \pm 101 \mathrm{a}$ & $4.4 \pm 0.0 \mathrm{a}$ \\
0.2 & $1,937 \pm 57 \mathrm{a}$ & $124.8 \pm 4.7 \mathrm{a}$ & $151.4 \pm 7.8 \mathrm{ab}$ & $6.5 \pm 0.3 \mathrm{ab}$ & $1,295 \pm 106 \mathrm{~b}$ & $3.7 \pm 0.0 \mathrm{a}$ \\
0.4 & $1,943 \pm 91 \mathrm{a}$ & $126.2 \pm 6.2 \mathrm{a}$ & $142.2 \pm 8.7 \mathrm{~b}$ & $6.4 \pm 0.2 \mathrm{ab}$ & $1,073 \pm 86 \mathrm{c}$ & $3.4 \pm 0.4 \mathrm{ab}$ \\
0.8 & $1,967 \pm 83 \mathrm{a}$ & $124.4 \pm 2.8 \mathrm{a}$ & $120.1 \pm 6.2 \mathrm{c}$ & $6.1 \pm 0.2 \mathrm{ab}$ & $940 \pm 27 \mathrm{~cd}$ & $2.5 \pm 0.8 \mathrm{bc}$ \\
1.0 & $1,953 \pm 72 \mathrm{a}$ & $127.7 \pm 3.6 \mathrm{a}$ & $103.1 \pm 2.5 \mathrm{~d}$ & $5.8 \pm 0.3 \mathrm{~b}$ & $862 \pm 82 \mathrm{~d}$ & $1.9 \pm 0.4 \mathrm{c}$ \\
\hline
\end{tabular}

Note: values deviation with different letters indicate significant difference at level of $P=0.05$. COD: chemical oxygen demand, total PO4 ${ }^{3-}$ : total phosphate, TN: total nitrogen, APC: aerobic plate counts. 
tration in dairy wastewater was increased from 10 to $90 \mathrm{mg} / \mathrm{L}$. The $\mathrm{pH}$ reduction is explained by the hypochlorite acid generated from the reaction of $\mathrm{NaClO}$ with water which can oxidize ammonia nitrogen into nitrogen gas and produce hydrochloric acid $\left(2 \mathrm{NH}_{3}+3 \mathrm{HClO}\right.$ $\rightarrow \mathrm{N}_{2} \uparrow+3 \mathrm{H}_{2} \mathrm{O}+3 \mathrm{HCl}$ ) (EPA, 2002; Estrela et al., 2002). As a strong and non-selective oxidant, chlorine can oxidize a wide spectrum of organics and bacteria. $\mathrm{NaClO}$ pretreatment removed $31-45 \%$ of true color and 0.7-2.5 log CFU/mL bacteria which improved light transmission and favor photosynthetic growth of microalgae. However, unlike physical autoclave more than $1.9 \mathrm{log}$ CFU/mL bacteria remained in the wastewater after $\mathrm{NaClO}$ pretreatment. Bacteria survival suggests that a higher dose might be needed in the pretreatment to reduce the bacteria load. However, the presence of chlorine-resistant bacteria strains was reported by Macauley et al. (2006) who found that chlorine dose higher than $30 \mathrm{mg} / \mathrm{L}$ did not achieve 100\% inactivation of bacteria in wastewater.

\subsection{Effect of $\mathrm{NaClO}$ pretreatment on microorganism growth}

\subsubsection{Growth of immobilized microalgae in beads}

Pretreatment of $\mathrm{NaClO}$ was reported to be able to benefit microalgae growth in wastewater by improving light transmission and generating chloride ions as algal micronutrients as well as reducing bacterial competition (Eyster, 1958). As shown in Fig. 1, following the one-day

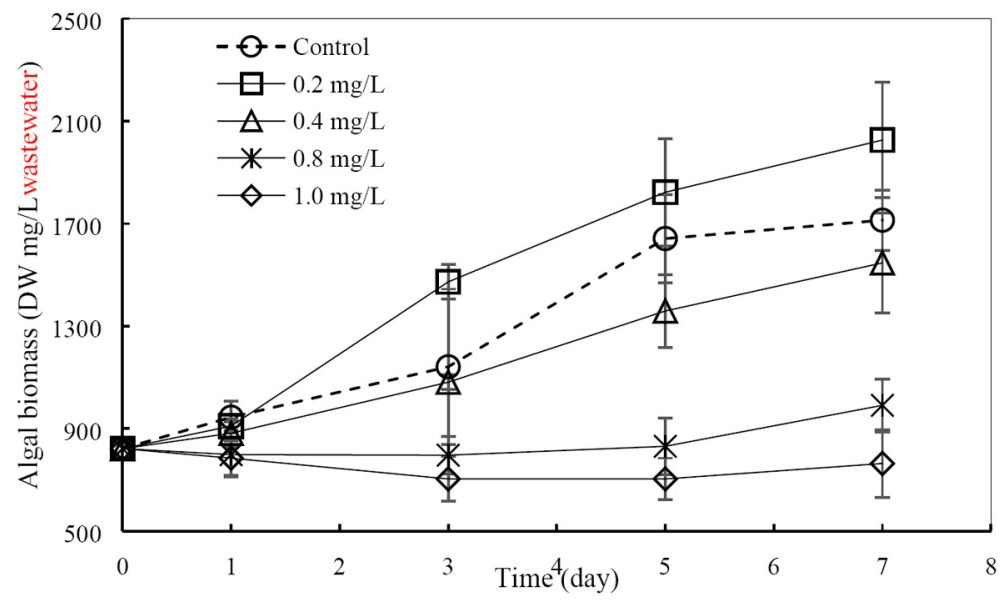

Fig. 1. Growth of microalgae in beads in wastewater with and without (control) $\mathrm{NaClO}$ pretreated. 
adaption period, immobilized microalgae growth in wastewater pretreated with 0.2 and $0.4 \mathrm{mg} / \mathrm{L}$ free chlorine showed a consecutive increase from 822 to 2,026 and 1,547 DW mg/L wastewater at the end of treatment. Furthermore, microalgae growth in wastewater pretreated with $0.2 \mathrm{mg} / \mathrm{L}$ free chlorine was significantly $(P<0.05)$ higher than control (1,714 DW mg/L wastewater) on day seven. However, despite the benefit of reducing native bacteria, chlorine-based disinfection is non-selective and the application of excess chlorine will increase salinity and be toxic to aquatic plants and organisms (Lv et al., 2018). As indicated in this study, pretreatment with 0.8 and $1.0 \mathrm{mg} / \mathrm{L}$ free chlorine extended the microalgae lag period. Therefore significant biomass increase was not observed in these pretreatments. Mutanda et al. (2011) found that wastewater pretreatment with 0.2 and $0.4 \mathrm{mg} / \mathrm{L}$ free chlorine supported higher algal biomass growth while dosage higher than $0.4 \mathrm{mg} / \mathrm{L}$ free chlorine was algicidal. Although they used a different system to cultivate microalgae (suspended algae growth) similar results were gained suggesting that chlorine oxidation is powerful and algal cells immobilized into alginate gel beads cannot be exempt from the chemical disinfection. Therefore, pretreatment with a free chlorine concentration of $0.2 \mathrm{mg} / \mathrm{L}$ is suitable to improve wastewater quality while promoting the growth of microalgae. However, algal biomass increase observed in this study $(0.15 \mathrm{mg} / \mathrm{bead})$ is significantly lower than the value reported $(0.45-0.62 \mathrm{mg} / \mathrm{bead})$ by Lam and Lee (2012). This is likely due to the high concentration of immobilized activated sludge and microalgae cells which increased the opacity of the beads and cause the self-shading effect to limit light penetration and microalgae growth (Ruiz-Marin et al., 2010).

\subsubsection{Growth of bacteria suspended in wastewater}

Change of bacterial load in wastewater with and without (control and blank) $\mathrm{NaClO}$ pretreatment was determined during the sevenday treatment. As shown in Fig. 2, after initiating the treatment, bacterial growth in non-pretreated (blank and control) and $0.2 \mathrm{mg} / \mathrm{L}$ free chlorine-pretreated wastewater entered into an exponential phase immediately while one-day lag phase was observed in wastewater pretreated with $0.4-1.0 \mathrm{mg} / \mathrm{L}$ free chlorine. This implies that free chlorine concentration higher than $0.2 \mathrm{mg} / \mathrm{L}$ was required to inhibit bacterial growth in wastewater. Also, a comparison of bacteria loads on the 


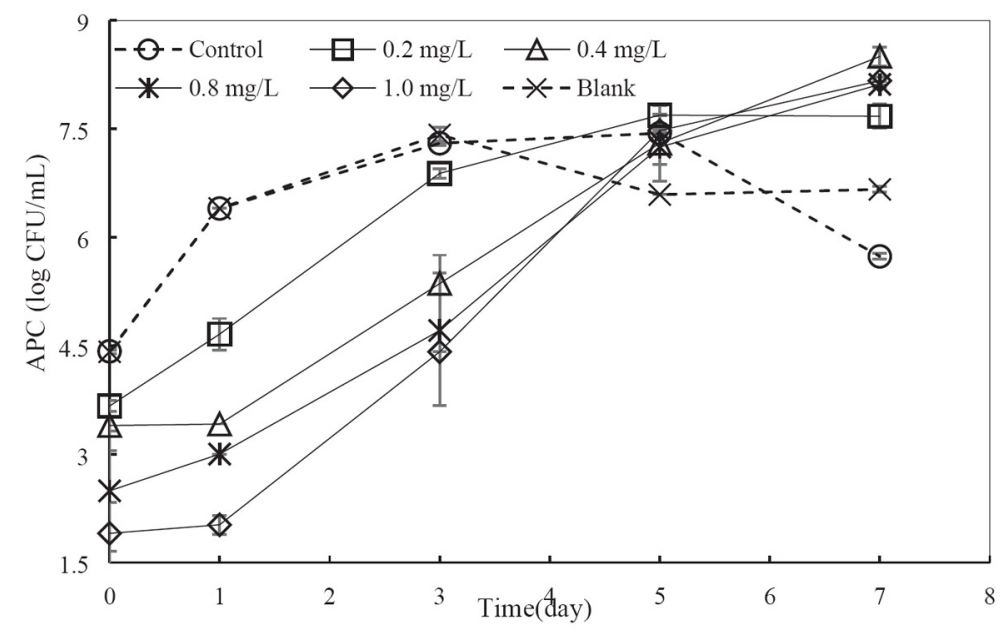

Fig. 2. Growth of bacteria suspended in wastewater with different free chlorine concentration. Control: non-pretreated wastewater + beads, Blank: non-pretreated wastewater + blank beads.

same day indicated that the adverse impact of free chlorine on bacterial growth in wastewater lasted for three days. On the third day, bacterial loads in $0.2,0.4,0.8,1.0 \mathrm{mg} / \mathrm{L}$ free chlorine-pretreated wastewater were 6.9, 5.4, 4.7, and $4.4 \log \mathrm{CFU} / \mathrm{mL}$, respectively, which were lower than control (7.3 log CFU/mL) and blank (7.4 log CFU/mL). However, despite the initial inhibitive effect, bacteria in $0.4-1.0 \mathrm{mg} / \mathrm{L}$ free chlorine-pretreated wastewater subsequently followed exponential growth and reached $8.1-8.5 \log \mathrm{CFU} / \mathrm{mL}$ at the end of treatment. This later recovery of bacterial loads in $\mathrm{NaClO}$-pretreated wastewater was attributed to the instability of free chlorine in water which resulted in a decrease of free chlorine concentration in wastewater (Olivieri et al., 1986). Also, the presence of a large amount of digestible organic nutrients in wastewater provided favorable conditions for bacterial growth (Qiang et al., 2006). Therefore, $\mathrm{NaClO}$ pretreatment did not present a consistent inhibitive impact on the growth of bacteria suspended in wastewater despite the initial disinfection.

\subsection{Impact of $\mathrm{NaClO}$ pretreatment on pollutants removal}

\subsubsection{Removal of $C O D$}

To determine the effect of indigenous bacteria and alginate gel on pollutants removal, the same amount of blank alginate gel beads 


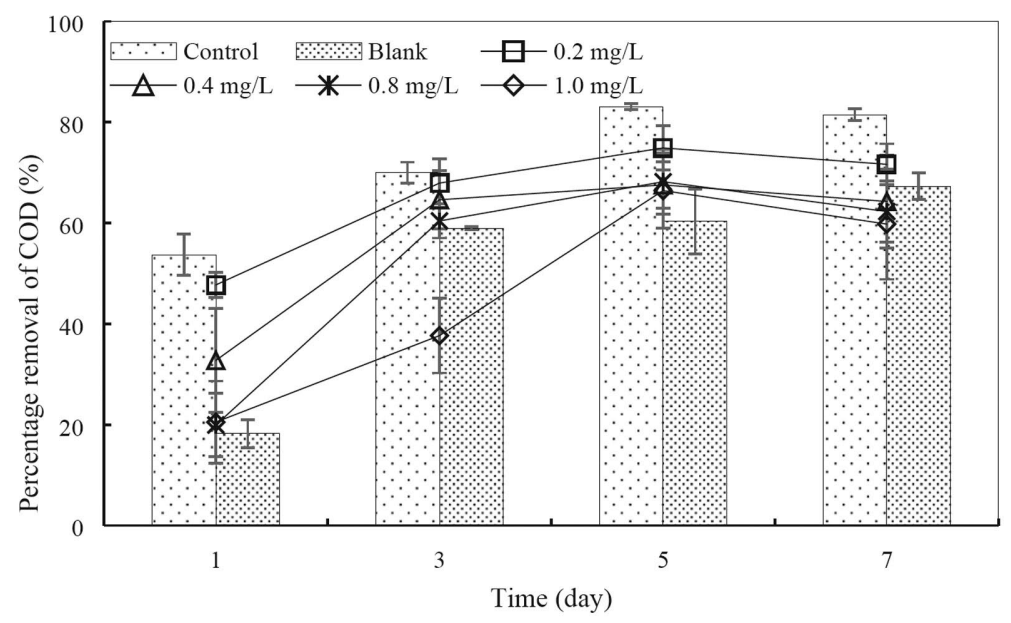

Fig. 3. Percentage removal of COD during seven-day treatment. Control: nonpretreated wastewater + beads, Blank: non-pretreated wastewater + blank beads.

were applied in non-pretreated wastewater. As shown in Fig. 3, blank treatment removed 67\% COD in the end and immobilized microorganisms accounted for an additional 15\% COD removal. This suggests that immobilized microorganisms increased biodegradation of COD but their contribution was less compared to the organic mineralization by indigenous bacteria suspended in the wastewater. Consequently, the effect of $\mathrm{NaClO}$ pretreatment on $\mathrm{COD}$ removal was found to be close to that on bacterial growth discussed in section 3.2.2. In the first three days, the removal rate of COD was reduced with the increase of free chlorine concentration. For instance, on the first day COD removal from wastewater with free chlorine of $0.2(48 \%)$ was significantly higher $(P<0.05)$ than $0.4(33 \%), 0.8(20 \%)$ and $1.0(21 \%) \mathrm{mg} / \mathrm{L}$ which agrees with the low metabolic activity of bacteria in the lag phase. A similar phenomenon was also reported by Qin et al. (2014), who found that increasing concentration of available chlorine from 10 to $50 \mathrm{mg} / \mathrm{L}$ in dairy wastewater reduced COD removal from $65.8 \%$ to $51.5 \%$. However, at the end of treatment removal of COD in $0.8(62 \%)$ and $1.0(60 \%), \mathrm{mg} / \mathrm{L}$ free chlorine-pretreated wastewater was significantly $(P<0.05)$ lower than control (82\%). This does not coordinate with the observation that bacterial loads in $0.8(8.1 \log \mathrm{CFU} / \mathrm{mL})$ and $1.0 \mathrm{mg} / \mathrm{L}(8.2 \log \mathrm{CFU} / \mathrm{mL}$ ) free chlorine-pretreated wastewater were higher than control $(5.7 \log \mathrm{CFU} / \mathrm{mL}$ ) at the end of treatment. Since the only difference between treatments of control and chlorinated 
(A)

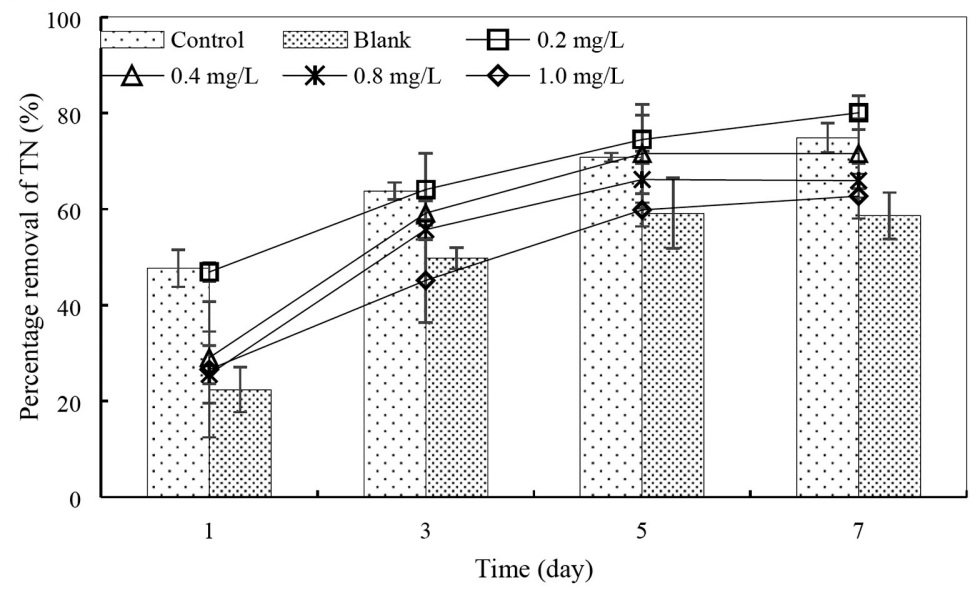

(B)

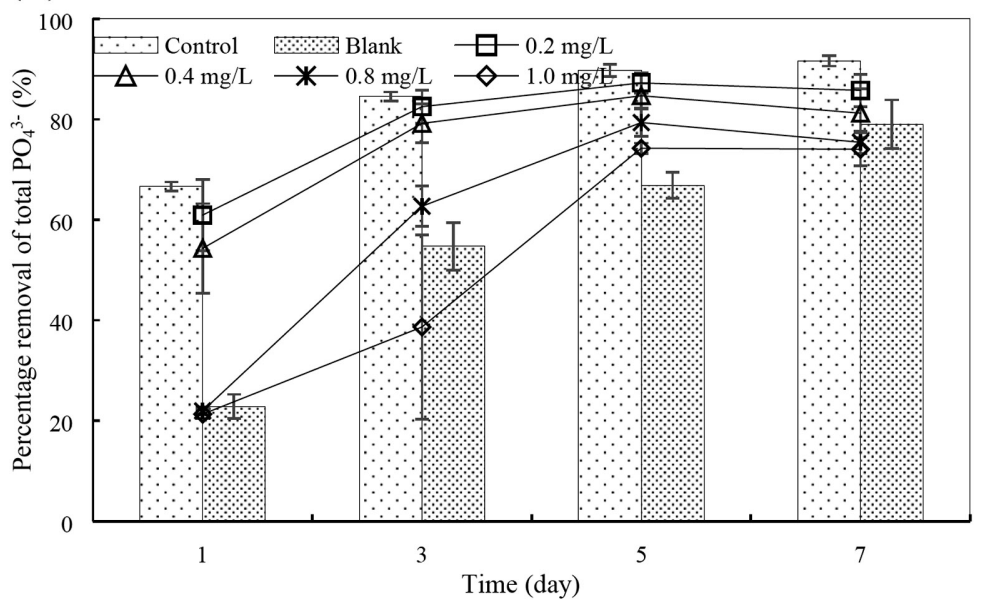

Fig. 4. Percentage removal of (a) $\mathrm{TN}$ and (b) total $\mathrm{PO} 4^{3-}$ from $\mathrm{NaClO}$ pretreated wastewater. Control: non-pretreated wastewater + beads, Blank: nonpretreated wastewater + blank beads.

wastewater was the presence of free chlorine, thus the possible reason is that immobilized microorganisms were inactivated by pretreatment of $0.8-1.0 \mathrm{mg} / \mathrm{L}$ free chlorine which was proved by the poor growth of algal biomass discussed in 3.2.1.

\subsubsection{Nutrients removal}

Fig. 4a demonstrated removal of TN from wastewater with and without (control and blank) $\mathrm{NaClO}$ pretreatment as a function of the treatment period. In wastewater without $\mathrm{NaClO}$ pretreatment, $\mathrm{TN}$ removal from the blank treatment kept a constant increase from $22 \%$ 
on day one until leveled off at $59 \%$. It was found by the authors that alginate gel could remove $33.1 \mathrm{mg} / \mathrm{L}$ TN through physiochemical adsorption such as ionic interaction with positive charged ammonium ions. In contrast to blank, beads in control removed $48 \%$ TN on day one and peaked at $75 \%$ suggesting that immobilized microorganisms took up $16 \%$ more TN than blank. Since sludge bacteria are far less efficient in nutrients removal than microalgae and microalgal assimilation should be the dominating biological process for TN removal (Katam and Bhattacharyya, 2019).

Consequently, $\mathrm{NaClO}$ pretreatment generated a similar effect on the biological removal of $\mathrm{TN}$ to the growth of immobilized microalgae. It was noticed that increasing concentration of free chlorine applied in the process of wastewater pretreatment reduced the TN removal during the seven-day treatment. For example, on the first day, TN removal decreased from $47 \%$ to $26-29 \%$ when free chlorine concentration raised from 0.2 to $0.4-1.0 \mathrm{mg} / \mathrm{L}$. Also, the removal of TN in wastewater pretreated with $0.8(63 \%)$ and 1.0 (66\%) $\mathrm{mg} / \mathrm{L}$ free chlorine were close to those observed in the blank treatment (59\%) and significantly $(P<0.05)$ lower than others. This implies that pretreatment with 0.8 and $1.0 \mathrm{mg} / \mathrm{L}$ free chlorine considerably lowered the activity of immobilized microorganisms, which correlates with the poor growth of immobilized microalgae. Nevertheless, pretreatment with $0.2 \mathrm{mg} / \mathrm{L}$ free chlorine slightly increased TN removal from $75 \%$ in control to $80 \%$ at the end of treatment. Such effect is related to the higher concentration of algal biomass in $0.2 \mathrm{mg} / \mathrm{L}$ free chlorine-pretreated wastewater.

Similar to nitrogen, phosphorus can be removed through physicochemical and biological ways in the alginate gel co-immobilized microalgae- slduge system. In the previous study, the authors noticed that alginate gel removed $30.6 \mathrm{mg} / \mathrm{L}$ more total $\mathrm{PO}_{4}{ }^{3-}$ than pure wastewater. Alginate has been reported to physically adsorb phosphate ions and release calcium ions into wastewater to form precipitation with phosphate under alkaline pH (Angela et al., 2011). As a result, although there were no microorganisms immobilized in blank beads, this treatment still removed $23 \%$ total $\mathrm{PO}_{4}{ }^{3-}$ on the first day and achieved a final removal of $79 \%$ from non-pretreated wastewater with the abiotic process (Fig. 4b). The only difference between blank and control was the immobilization of microorganisms. Total $\mathrm{PO}_{4}{ }^{3-}$ removal in control reached $63 \%$ and gradually increased to $92 \%$ at the 
end, which was significantly $(P<0.05)$ higher than blank treatment. This means that immobilized microorganisms accelerated the process of phosphorus removal and removed $13 \%$ more total $\mathrm{PO}_{43}$. However, pretreatment with $\mathrm{NaClO}$ did not enhance this biological process of removing phosphorus. Total $\mathrm{PO}_{4}{ }^{3-}$ removal from wastewater pretreated with 0.2 and $0.4 \mathrm{mg} / \mathrm{L}$ free chlorine were close to control and increased steadily from $61 \%$ to $83 \%$ and $54 \%$ to $79 \%$ within the first three days before being stabilized at $86 \%$ and $81 \%$ in the end. While pretreatment with 0.8 and $1.0 \mathrm{mg} / \mathrm{L}$ free chlorine reduced removal of phosphorus and merely $22 \%$ total $\mathrm{PO}_{4}{ }^{3-}$ was removed the beginning of the treatment corresponding to the weak growth of microorganisms in wastewater. Sharp increases were observed later, and total $\mathrm{PO}_{4}{ }^{3-}$ removal from 0.8 and $1.0 \mathrm{mg} / \mathrm{L}$ free chlorine increased to $79 \%$ and $74 \%$ on the fifth day. This trend is more related to the growth of bacteria in wastewater than immobilized microalgae. In terms of removal of phosphorus, intake by both microalgae and bacteria should be considered. In the activated sludge, some bacteria species can conduct luxury phosphorus uptake which refers to the storage of excess phosphorus in the form of polyphosphate under an aerobic environment and release them back to wastewater under anaerobic condition (Wentzel, 1988). Pretreatments of 0.8 and $1.0 \mathrm{mg} / \mathrm{L}$ free chlorine were toxic to immobilized microalgae and phosphorus uptake by algal cells was limited. Thus, luxury phosphorus removal by activated sludge bacteria dominated.

Nitrogen and phosphorus are essential elements for microalgae growth. Although $\mathrm{NaClO}$ pretreatment improved wastewater environment, it did not significantly $(P>0.05)$ increase nutrients removal, which suggests the tough resistance of this co-immobilized system to the harsh real industrial wastewater environment. After seven-day treatment, the concentration of $\mathrm{TN}$ and total $\mathrm{PO}_{4}{ }^{3-}$ in control and 0.2 $\mathrm{mg} / \mathrm{L}$ free chlorine-pretreated wastewater were reduced to $30-39.0$ and $10.5-17.7 \mathrm{mg} / \mathrm{L}$, respectively.

\section{Conclusions}

$\mathrm{NaClO}$ pretreatment improved wastewater environment, and the application of $0.2 \mathrm{mg} / \mathrm{L}$ free chlorine increased microalgae growth. The negative effect of free chlorine on bacterial growth was observed in 
the first three days but diminished later. Immobilized microorganisms functioned well and removed more pollutants from wastewater than blank gel beads. However, pretreatment with free chlorine $>0.2 \mathrm{mg} / \mathrm{L}$ decreased immobilized microorganisms' activity and pollutants removal. Finally, $72-82 \%$ COD, 75-80\% TN and $86-92 \%$ total $\mathrm{PO}_{4}{ }^{3-}$ were removed from control and $0.2 \mathrm{mg} / \mathrm{L}$ free chlorine pretreated wastewater. This study suggests that $\mathrm{NaClO}$ pretreatment was beneficial but not essential to improve the performance of the co-immobilized microalgae/bacteria system.

CRediT authorship contribution statement - Xinjuan Hu: Investigation, Validation, Formal analysis, Data curation, Writing - original draft. Yulie E. Meneses: Methodology, Resources, Writing - review \& editing, Supervision, Project administration, Funding acquisition. Ashraf Aly Hassan: Conceptualization, Methodology, Resources, Writing - review \& editing, Funding acquisition.

Declaration of Competing Interest - The authors declare that they have no known competing financial interests or personal relationships that could have appeared to influence the work reported in this paper.

Acknowledgments - The authors would like to thank the support from the United States Geological Survey (USGS) and the Water for Food Daugherty Global Institute. The authors also would like to express their gratitude to the National Water Center at United Arab Emirates University (UAEU) for partly financing this project under [grant number G00003296].

Appendix - Supplementary data follows the References.

\section{References}

Angela, M., Beatrice, B., Mathieu, S., 2011. Biologically induced phosphorus precipitation in aerobic granular sludge process. Water Res. 45 (12), 3776-3786.

Anthony, R.J., Ellis, J.T., Sathish, A., Rahman, A., Miller, C.D., Sims, R.C., 2013. Effect of coagulant/flocculants on bioproducts from microalgae. Bioresour. Technol. 149, 65-70.

Barros, A.I., Goncalves, A.L., Simoes, M., Pires, J.C., 2015. Harvesting techniques applied to microalgae: a review. Renew. Sustain. Energy Rev. 41, 1489-1500.

Cheirsilp, B., Thawechai, T., Prasertsan, P., 2017. Immobilized oleaginous microalgae for production of lipid and phytoremediation of secondary effluent from palm oil mill in fluidized bed photobioreactor. Bioresour. Technol. 241, 787-794. 
Cruz, I., Bashan, Y., Hernandez-Carmona, G., De-Bashan, L.E., 2013. Biological deterioration of alginate beads containing immobilized microalgae and bacteria during tertiary wastewater treatment. Applied microbiology and biotechnology 97 (22), 9847-9858.

de-Bashan, L.E., Bashan, Y., Moreno, M., Lebsky, V.K., Bustillos, J.J., 2002. Increased pigment and lipid content, lipid variety, and cell and population size of the microalgae Chlorella spp. when co-immobilized in alginate beads with the microalgaegrowth- promoting bacterium Azospirillum brasilense. Can J. Microbiol. 48 (6), 514-521.

de-Bashan, L.E., Bashan, Y., 2010. Immobilized microalgae for removing pollutants: review of practical aspects. Bioresour. Technol. 101 (6), 1611-1627.

EPA, U., 2002. Development document for the proposed effluent limitations guidelines and standards for the meat and poultry products industry point source category (40 CFR 432).

Estrela, C., Estrela, C.R., Barbin, E.L., Spano, J.C.E., Marchesan, M.A., Pecora, J.D., 2002. Mechanism of action of sodium hypochlorite. Braz. Dent. J. 13 (2), 113-117.

Eyster, C., 1958. Chloride effect on the growth of Chlorella pyrenoidosa. Nature 181 (4616), 1141.

Farooq, W., Lee, Y.-C., Ryu, B.-G., Kim, B.-H., Kim, H.-S., Choi, Y.-E., Yang, J.-W., 2013. Two-stage cultivation of two Chlorella sp. strains by simultaneous treatment of brewery wastewater and maximizing lipid productivity. Bioresour. Technol. 132, 230-238.

Goncalves, A.L., Pires, J.C.M., Simoes, M., 2016. Wastewater polishing by consortia of Chlorella vulgaris and activated sludge native bacteria. J. Cleaner Prod. 133, 348-357.

Gupta, S., Pawar, S.B., 2018. An integrated approach for microalgae cultivation using raw and anaerobic digested wastewaters from food processing industry. Bioresour. Technol. 269, 571-576.

$\mathrm{HACH}$, 20Platinum-Cobalt Standard Method.

Hariz, H.B., Takriff, M.S., Yasin, N.H.M., Ba-Abbad, M.M., Hakimi, N.I.N.M., 2019. Potential of the microalgae-based integrated wastewater treatment and $\mathrm{CO} 2 \mathrm{fix}-$ ation system to treat Palm Oil Mill Effluent (POME) by indigenous microalgae: Scenedesmus sp. and Chlorella sp. J. Water Process Eng. 32, 100907.

Hodaifa, G., Martinez, M.E., Sanchez, S., 2008. Use of industrial wastewater from olive-oil extraction for biomass production of Scenedesmus obliquus. Bioresour. Technol. 99 (5), 1111-1117.

Katam, K., Bhattacharyya, D., 2019. Simultaneous treatment of domestic wastewater and bio-lipid synthesis using immobilized and suspended cultures of microalgae and activated sludge. J. Ind. Eng. Chem. 69, 295-303.

Lam, M.K., Lee, K.T., 2012. Immobilization as a feasible method to simplify the separation of microalgae from water for biodiesel production. Chem. Eng. J. 191, 263-268.

Lin, C.-Y., Nguyen, M.-L.T., Lay, C.-H., 2017. Starch-containing textile wastewater treatment for biogas and microalgae biomass production. J. Cleaner Prod. 168, 331-337. 
Lv, J., Liu, Y., Feng, J., Liu, Q., Nan, F., Xie, S., 2018. Nutrients removal from undiluted cattle farm wastewater by the two-stage process of microalgae-based wastewater treatment. Bioresour. Technol. 264, 311-318.

Macauley, J.J., Qiang, Z., Adams, C.D., Surampalli, R., Mormile, M.R., 2006. Disinfection of swine wastewater using chlorine, ultraviolet light and ozone. Water Res. 40 (10), 2017-2026.

Maity, J.P., Bundschuh, J., Chen, C.-Y., Bhattacharya, P., 2014. Microalgae for third generation biofuel production, mitigation of greenhouse gas emissions and wastewater treatment: Present and future perspectives - A mini review. Energy 78, 104-113.

Markou, G., Chatzipavlidis, I., Georgakakis, D., 2012. Cultivation of Arthrospira (Spirulina) platensis in olive-oil mill wastewater treated with sodium hypochlorite. Bioresour. Technol. 112, 234-241.

Mujtaba, G., Rizwan, M., Lee, K., 2017. Removal of nutrients and COD from wastewater using symbiotic co-culture of bacterium Pseudomonas putida and immobilized microalga Chlorella vulgaris. J. Ind. Eng. Chem. 49, 145-151.

Mutanda, T., Karthikeyan, S., Bux, F., 2011. The utilization of post-chlorinated municipal domestic wastewater for biomass and lipid production by Chlorella spp. under batch conditions. Appl. Biochem. Biotechnol. 164 (7), 1126-1138.

Olivieri, V.P., Snead, M.C., Kruse, C.W., Kawata, K., 1986. Stability and effectiveness of chlorine disinfectants in water distribution systems. Environ. Health Perspect. 69, 15-29.

Park, S., Van Ginkel, S.W., Pradeep, P., Igou, T., Yi, C., Snell, T., Chen, Y., 2016. The selective use of hypochlorite to prevent pond crashes for algae-biofuel production. Water Environ. Res. 88 (1), 70-78.

Plummer, J.D., Edzwald, J.K., 2002. Effects of chlorine and ozone on algal cell properties and removal of algae by coagulation. J. Water Supply: Res. Technol.AQUA 51 (6), 307-318.

Qiang, Z., Macauley, J.J., Mormile, M.R., Surampalli, R., Adams, C.D., 2006. Treatment of antibiotics and antibiotic resistant bacteria in swine wastewater with free chlorine. J. Agric. Food. Chem. 54 (21).

Qin, L., Shu, Q., Wang, Z., Shang, C., Zhu, S., Xu, J., Li, R., Zhu, L., Yuan, Z., 2014. Cultivation of Chlorella vulgaris in dairy wastewater pretreated by UV irradiation and sodium hypochlorite. Appl. Biochem. Biotechnol. 172 (2), 1121-1130.

Ruiz-Marin, A., Mendoza-Espinosa, L.G., Stephenson, T., 2010. Growth and nutrient removal in free and immobilized green algae in batch and semi-continuous cultures treating real wastewater. Bioresour. Technol. 101 (1), 58-64.

Shen, Y., Gao, J., Li, L., 2017. Municipal wastewater treatment via co-immobilized microalgal- bacterial symbiosis: Microorganism growth and nutrients removal. Bioresour. Technol. 243, 905-913.

Starr, R.C., Zeikus, J.A., 1993. UTEX-The culture collection of algae at the University of Texas at Austin 1993 list of cultures 1. J. Phycol. 29, 1-106.

Su, H., Zhang, Y., Zhang, C., Zhou, X., Li, J., 2011. Cultivation of Chlorella pyrenoidosa in soybean processing wastewater. Bioresour. Technol. 102 (21), 9884-9890. 
Tan, X.-B., Zhao, X.-C., Yang, L.-B., Liao, J.-Y., Zhou, Y.-Y., 2018. Enhanced biomass and lipid production for cultivating Chlorella pyrenoidosa in anaerobically digested starch wastewater using various carbon sources and up-scaling culture outdoors. Biochem. Eng. J. 135, 105-114.

Taşkan, E., 2016. Performance of mixed algae for treatment of slaughterhouse wastewater and microbial community analysis. Environ. Sci. Pollut. Res. 23 (20), 20474-20482.

Wang, H., Zhang, W., Chen, L., Wang, J., Liu, T., 2013. The contamination and control of biological pollutants in mass cultivation of microalgae. Bioresour. Technol. 128, 745-750.

Wang, W.L., Zhang, X., Wu, Q.Y., Du, Y., Hu, H.Y., 2017. Degradation of natural organic matter by UV/chlorine oxidation: molecular decomposition, formation of oxidation byproducts and cytotoxicity. Water Res. 124, 251-258.

Wang, Y., Guo, W., Yen, H.-W., Ho, S.-H., Lo, Y.-C., Cheng, C.-L., Ren, N., Chang, J.-S., 2015. Cultivation of Chlorella vulgaris JSC- 6 with swine wastewater for simultaneous nutrient/COD removal and carbohydrate production. Bioresour. Technol. 198, 619-625.

Wentzel, M.C., 1988. Biological excess phosphorus removal in activated sludge systems. University of Cape Town.

Xie, B., Gong, W., Yu, H., Tang, X., Yan, Z., Luo, X., Gan, Z., Wang, T., Li, G., Liang, H., 2018. Immobilized microalgae for anaerobic digestion effluent treatment in a photobioreactor- ultrafiltration system: Algal harvest and membrane fouling control. Bioresour. Technol. 268, 139-148.

Yang, L., Li, H., Wang, Q., 2019. A novel one-step method for oil-rich biomass production and harvesting by co-cultivating microalgae with filamentous fungi in molasses wastewater. Bioresour. Technol. 275, 35-43.

Zhu, L., Qin, X., Xu, Z., Qin, L., Hiltunen, E., Takala, J., Wang, Z., Yuan, Z., 2013. Scale-up potential of cultivating Chlorella zofingiensis in piggery wastewater for biodiesel production. Bioresour. Technol. 137, 318-325. 


\section{Appendix - Supplementary data}

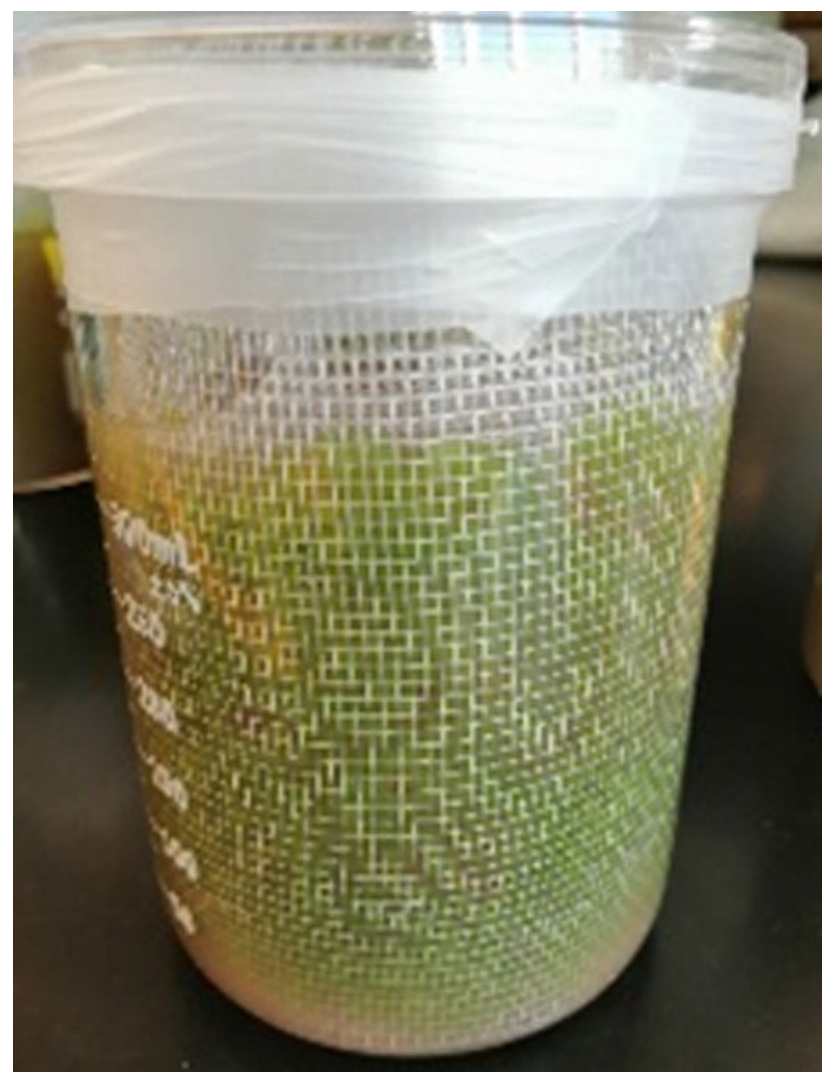

Fig. S1. Picture and image of annular bioreactor.

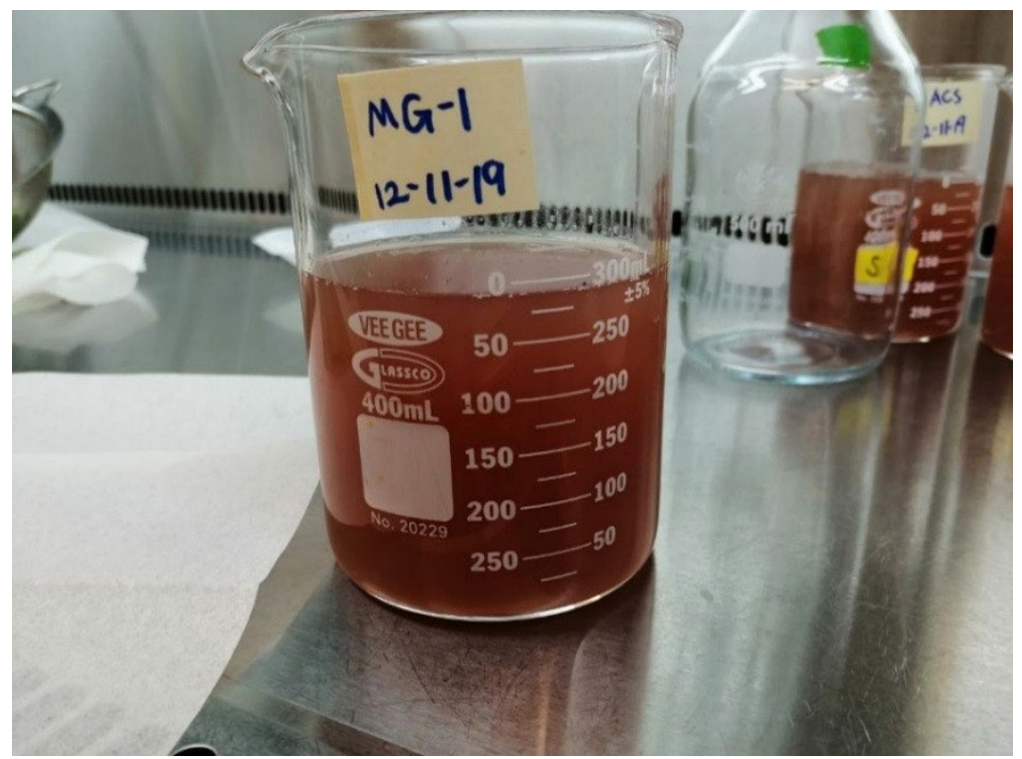

Fig. S2. Wastewater collected from a dissolved air flotation tank in a local meat processing plant. 

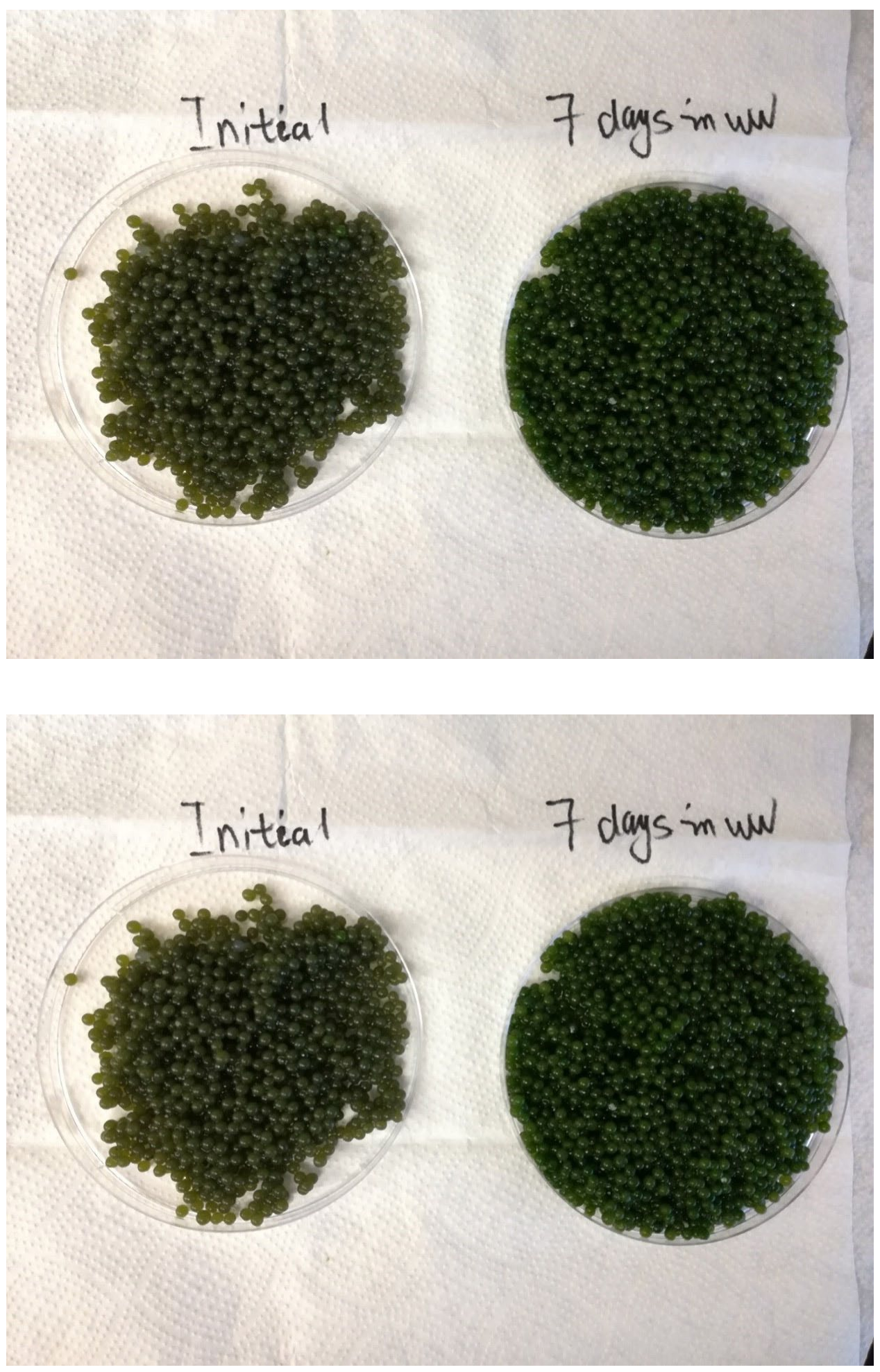

Fig. S3. Image of beads prepared at the beginning of the experiment (day 0 ) and beads being cultivated in non-pretreated wastewater for 7 days (day 7 ). 

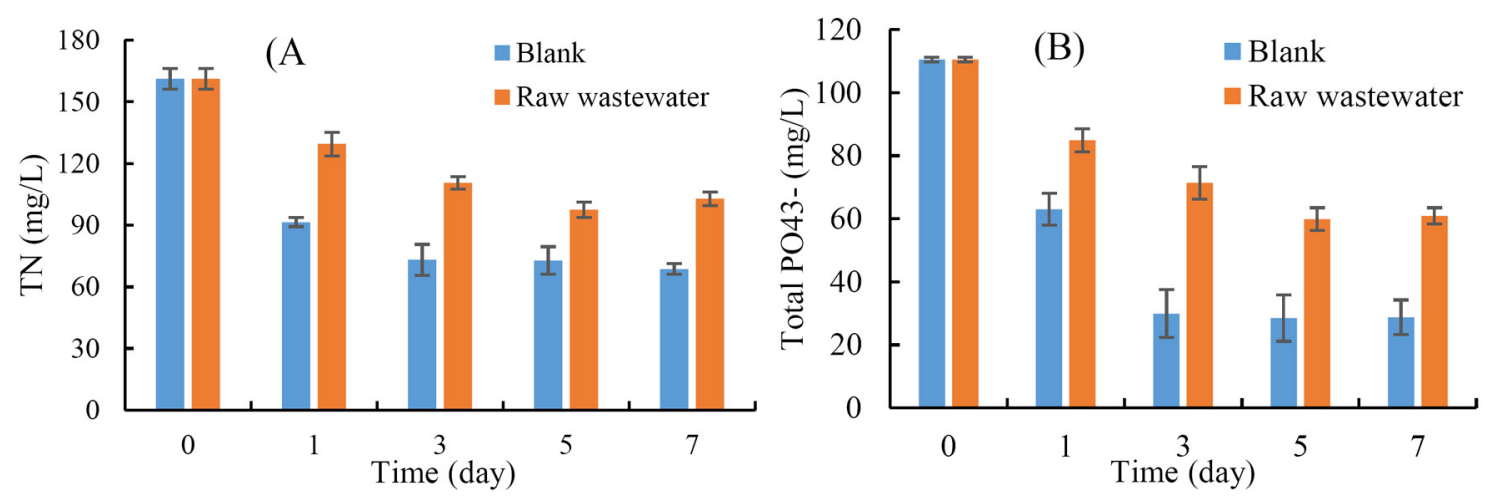

Fig. S4. Change of concentration of $\mathrm{TN}(\mathrm{A})$ and total $\mathrm{PO}_{4}{ }^{3-}(\mathrm{B})$ in raw wastewater and blank treatment (non-pretreated raw wastewater + blank gel beads). 